\title{
Do Arsenal de Guerra para o mundo operário mais amplo: estudo centrado na Sociedade Bolsa de Caridade (1872-1930)
}

From the War Arsenal to a wider labour world: a study focused on the Society for Charity Funds (1872-1930)

\section{Celina Batalha Oliveira Lima*}

Resumo: A Sociedade Bolsa de Caridade do Arsenal de Guerra da Bahia foi fundada em 8 de maio de 1872. De início, tratava-se de uma associação mutualista fechada, restrita aos operários daquela instituição. Ela foi gradualmente eliminando entraves, até tornar-se uma agremiação aberta aos indivíduos de qualquer ocupação, sexo ou nacionalidade. A presente pesquisa acompanhou a trajetória da associação desde a sua fundação, até o ano de 1930, buscando compreender o que representava o associativismo mutualista para os próprios filiados ao longo desse período. Nesse sentido, este artigo procura apresentar a composição social da agremiação e a rede de relações de seus membros com outras associações de auxílio-mútuo, especialmente a avultada participação de seus filiados no corpo diretivo de diversas outras sociedades operárias de Salvador.

Palavras-chave: Sociedade Bolsa de Caridade; mutualismo; associativismo operário; Arsenal de Guerra da Bahia.

Abstract: The Society for Charity Funds of the War Arsenal of Bahia was founded on 8 May 1872 as a mutual aid association exclusive to the War Arsenal workers. After some struggle it gradually became accessible for workers of any occupation, gender and nationality. This research traces the trajectory of this association since its foundation in 1872 until 1930, trying to understand what this mutual aid association represented for its own members during this period. This article presents the social composition of the association and the network of relations between its members and the many other mutual aid organizations members, especially the significant participation of its members on boards of directors of the various labor societies in Salvador.

Keywords: Society for Charity Funds; mutualism; labor association; War Arsenal of Bahia.

Graduada em História, pela Universidade Federal da Bahia (UFBA). Mestre em História, pela Universidade do Estado da Bahia (UNEB). E-mail: batalhacelina@gmail.com. ORCID: https://orcid.org/0000-0002-0347-3466. 
No dia 21 de agosto de 1889, José Jorge Lucas Pinto, mestre da oficina de maquinista do Arsenal de Guerra da Bahia, encaminhou ao presidente da província o seu pedido de aposentadoria aos órgãos competentes. ${ }^{1}$ Entre os trabalhadores do Arsenal, poucos eram os que faziam jus a essa graça. Somente os militares de carreira contavam com alguma proteção governamental que lhes garantia certos direitos, a exemplo de licença saúde e aposentadoria. Portanto, os que trabalhavam por jornada ou empreitada, bem como os que tinham patentes militares honoríficas, não estavam assegurados pelas vantagens garantidas aos militares de carreira, ainda que uns e outros convivessem e trabalhassem lado a lado no referido Arsenal. No período abarcado por este artigo (1872-1930), a incipiente proteção social ainda era um direito conquistado por poucos.

Efetivamente, durante todo o século XIX e até as primeiras décadas do século $\mathrm{XX}$, de modo geral, os trabalhadores não contavam com a segurança de um sistema previdenciário governamental. Assim como ocorreu em diversos países, também no Brasil os que labutavam nos canteiros de obras e nas oficinas procuraram diminuir essa insegurança criando e filiando-se a associações de auxílio-mútuo. A quantidade de associações mutualistas em funcionamento no início do século $X X$ comprova a importância desse associativismo. Um levantamento (ainda que parcial e incompleto) feito pelas autoridades governamentais dava conta de que existiam pelo menos 3.505 sociedades beneficentes e mutualistas no país, em 1917, sendo 165 na Bahia. ${ }^{2}$ As associações mutualistas eram muito diversas em termos de tamanho, força e número de membros, abrangência e perfil dos associados, tendo em comum a ajuda mútua entre os filiados. ${ }^{3}$

Desde a primeira metade do século XIX, surgiram e se multiplicaram centenas de associações de auxílio-mútuo de trabalhadores no Brasil. A precariedade das condições de vida e de trabalho tornava muito curta a distância entre uma vida modesta e a miséria. A perda de um posto de trabalho, a doença, a invalidez ou a velhice eram espectros que assombravam sobremaneira os trabalhadores. Para uma parcela dos trabalhadores, foi o associativismo calcado no socorro mútuo que possibilitou o amparo, a autonomia e a dignidade que o Estado brasileiro Ihes

1 Correspondências recebidas do Diretor do Arsenal de Guerra da Bahia. Cx 3355 . Ofício n. 3062. Arquivo Público do Estado da Bahia (APEB). Seção Colonial e Provincial.

2 BRASIL. Anuário Estatístico do Brasil (1936). Rio de Janeiro: IBGE, 1936. v. 2 apud CASTELLUCCI, Aldrin A. S. A luta contra a adversidade: notas de pesquisa sobre o mutualismo na Bahia (1832-1930). Revista Mundos do Trabalho, v. 2, n. 4, p. 42, 2010.

3 LUCA, Tania Regina de. 0 sonho do futuro assegurado: o mutualismo em São Paulo. São Paulo: Contexto; Brasília; DF: CNPq, 1990. p. 24. 
negava. ${ }^{4}$ A fundação da associação objeto deste artigo não fugiu à regra. Os trabalhadores do Arsenal de Guerra perceberam a necessidade de ter uma associação própria, por ocasião do sepultamento de um companheiro de trabalho, veterano da Guerra do Paraguai (1864-1870), enterrado como indigente. Esse acontecimento expôs a fragilidade da condição social dos empregados do referido Arsenal e aguçou no grupo o temor de que outros operários também fossem vítimas de um enterro indigno. ${ }^{5}$

Neste artigo, investi na reconstituição da história da associação e procurei saber quem eram aqueles sujeitos que fundaram e tocaram a entidade por anos, buscando valorizar as experiências dos trabalhadores e investigar como suas práticas integravam o associativismo operário. Como parte desse esforço, busquei compreender as relações dos filiados da Bolsa de Caridade com as demandas mais gerais da classe trabalhadora, uma vez que $13 \%$ dos associados integraram a administração de diversas outras mutuais de trabalhadores, algumas delas comprometidas com a conquista de direitos para seus filiados, por meio da sua inserção na política formal, a exemplo do Centro Operário da Bahia, enquanto outras priorizavam a defesa do ofício, a exemplo da Associação Tipográfica Baiana.

As fontes utilizadas foram os estatutos de 1872, 1879, 1892, 1900 e 1909 da Sociedade Bolsa de Caridade (SBC); os demonstrativos de receitas e despesas dos exercícios de 1875-1887 (exceto 1884-1885) da SBC; os relatórios anuais do longo período de 1887-1930 (exceto 1894-1895) da SBC; os relatórios de outras associações de ajuda mútua de trabalhadores de Salvador; os jornais, revistas e almanaques publicados na Bahia no período; os inventários e testamentos dos associados da SBC e os Relatórios dos Trabalhos do Conselho Interino do Governo (BA) - 1823-1889. Essas fontes foram pesquisadas na Seção de Obras Raras e Seção de Periódicos Raros da Biblioteca Pública do Estado da Bahia (BPEB); na Seção de Arquivos Coloniais e Provinciais, Seção Republicana e Biblioteca do Arquivo Público do Estado da Bahia (APEB), ambos em Salvador; no Arquivo da Sociedade Bolsa de Caridade, sob a guarda da Sociedade Montepio dos Artistas, em Salvador; no Acervo de Memória e Documentação Clemente Mariani (AMDOC), na

4 Sobre o assunto, cf. CASTELLUCCI, Aldrin A. S. A luta contra a adversidade. In: MAC CORD, Marcelo; BATALHA, Claudio H. M. (org.). Organizar e proteger: trabalhadores, associações e mutualismo no Brasil (séculos XIX e XX). Campinas: Ed. Unicamp, 2014.

5 RELATÓRIO da Sociedade Bolsa de Caridade Exercício de 1922-1923 Relatado pelo Presidente do Diretório J. Prudencio F. de Carvalho em Assembleia Geral de 1 de Agosto de 1923 e na Mesma Unanimemente Aprovado. Bahia: Typographia do Lyceu de Artes, 1923. p. 6. 
Universidade Federal do Recôncavo da Bahia (UFRB, Campus de Cachoeira); e na Hemeroteca Digital da Biblioteca Nacional (BNDigital).

Este artigo se propõe a ser mais uma contribuição para os estudos do mutualismo no Brasil, a partir do caso da Sociedade Bolsa de Caridade. O acúmulo de pesquisas sobre o associativismo mutualista de trabalhadores tem o potencial de ampliar as possibilidades do entendimento das especificidades, mas também do que há em comum no fenômeno.

\section{Fundação e trajetória da Sociedade Bolsa de Caridade}

Em 1884, D. Maria da Gloria Machado, viúva do tenente honorário Christovão Francisco de Souto Cavalcante, comandante da Companhia de Menores do Arsenal de Guerra da Bahia, teve negado seu pleito de auxílio para as despesas funerárias do finado marido. O Arsenal alegou que o decreto do Ministério da Guerra previa esse benefício apenas para os militares de carreira. ${ }^{6}$ Como Christovão não era membro da Sociedade Bolsa de Caridade e não contava com o amparo governamental, sua viúva teria que arcar com todas as despesas funerárias, a menos que o finado pertencesse a outra associação de auxílio-mútuo.

Nem todos os trabalhadores do Arsenal agiram como o finado tenente. Muitos buscaram o associativismo como forma de proteção para os momentos de infortúnio, especialmente para garantir um funeral digno. Antes de contarem com uma associação própria, os trabalhadores do Arsenal de Guerra da Bahia e do Arsenal de Marinha da Bahia costumavam associar-se a uma das primeiras agremiações de auxílio-mútuo da então província, a Sociedade Montepio dos Artífices da Bahia, fundada em 16 de dezembro de 1832, sob a proteção de Nossa Senhora de Santana. Os artesãos dos dois arsenais também se vincularam à dissidência da Sociedade Montepio dos Artífices da Bahia, a Sociedade Montepio dos Artistas, criada em 2 de fevereiro de 1853, tendo Nossa Senhora da Purificação como padroeira. As duas mutuais dispunham de carneiros no cemitério das irmandades na Quinta dos Lázaros, evidência da forte influência da religiosidade católica popular e dos estreitos vínculos existentes entre irmandades e sociedades de socorros mútuos. Três anos mais tarde, em 13 de junho 1856 - dia de Santo Antonio -, uma terceira entidade foi fundada, a Sociedade Humanitária dos Artistas, protagonizada pelos calafates e carpinteiros do Arsenal de

6 Correspondência recebida do diretor do Arsenal de Guerra da Bahia, maço 3335. APEB. Seção de Arquivos Coloniais e Provinciais, Presidência da Província, Série Militares. 
Marinha. ${ }^{7}$ Por fim, em 8 de maio de 1872, liderados por Justino Pereira de Britto, alferes honorário do Exército graças aos "serviços prestados" na Guerra do Paraguai (18641870) e contramestre (depois mestre) das oficinas de latoeiros e funileiros do Arsenal de Guerra, criou-se a Sociedade Bolsa de Caridade do Arsenal de Guerra da Bahia. ${ }^{8}$ A Bolsa de Caridade tinha Nossa Senhora do Noviciado como padroeira, reiteração das fortes conexões e compartilhamento de experiências entre os membros das irmandades e das mutuais. ${ }^{9}$

A Sociedade Bolsa de Caridade dos Empregados e Operários do Arsenal de Guerra da Bahia tinha o objetivo inicial de proporcionar um funeral digno para os associados, antiga preocupação das irmandades. O auxílio-funeral no valor de 50 mil-réis era, portanto, o único amparo oferecido pela associação no momento de sua fundação, ainda que já se apontasse em seu primeiro estatuto para a possibilidade de oferecer "pensões entre seus associados conforme o progresso de sua estabilidade e rendimentos de seus capitais". Esse auxílio seria dado aos que necessitassem de "socorros por motivo de moléstia" que os impossibilitassem de "obter os meios necessários à sua subsistência". ${ }^{10}$ Nos três primeiros anos de sua existência, a Bolsa de Caridade funcionou em um cômodo do próprio Arsenal, sob a "proteção" do Coronel de Engenheiros Tomaz da Silva Paranhos, diretor do Arsenal. Somente os empregados dessa instituição poderiam ser sócios efetivos. Seus familiares, incluindo as mulheres, poderiam integrar a associação e usufruir dos socorros, mas não tinham direitos políticos. Enquanto funcionou nas dependências do Arsenal, o grau de autonomia da associação parece ter sido mínimo. O fato de a contribuição obrigatória dos sócios responder por apenas $20 \%$ das suas receitas anuais, bem como a proximidade física com a diretoria do Arsenal contribuíam para a pouca autonomia da mutual. A associação era mantida pelas subscrições que

7 CASTELLUCCI, Aldrin A. S. O associativismo mutualista na formação da classe operária em Salvador (1832-1930). In: MAC CORD, Marcelo; BATALHA, Claudio H. M. (org.). Organizar e proteger: trabalhadores, associações e mutualismo no Brasil (séculos XIX e XX). Campinas: Editora da Unicamp, 2014. p. 47-82. Apesar de muito importante, não há um estudo específico sobre o trabalho e a organização dos trabalhadores no Arsenal de Marinha da Bahia. O tema foi desenvolvido para o caso da Corte Imperial por David Lacerda. LACERDA, David Patrício. Trabalho, política e solidariedade operária: uma história social do Arsenal de Marinha do Rio de Janeiro (c. 1860 - c. 1890). 2016. Tese (Doutorado em História) - Universidade Estadual de Campinas, Campinas, 2016.

8 RELATÓRIO, op. cit., 1923. p. 6.

9 Para uma análise aprofundada sobre as relações entre irmandades e mutuais, cf. CASTELLUCCI, op. cit., 2014; LEITE, Douglas Guimarães. Mutualistas, graças a Deus: identidade de cor, tradições e transformações do mutualismo popular na Bahia do século XIX (1831-1869). 2017. Tese (Doutorado em História Social), Universidade de São Paulo, São Paulo, 2017.

10 ESTATUTOS da Sociedade Bolsa de Caridade dos Empregados e Operários do Arsenal de Guerra da Bahia, de 8 de maio de 1872. Bahia: Tipografia de J. G. Tourinho, 1873. p. 3-4. 
respondiam por aproximadamente $70 \%$ das suas receitas anuais, sendo provável que a influência do diretor fosse determinante para a obtenção dessa verba. Em 1877, talvez buscando certa independência econômica e um maior protagonismo dos trabalhadores na condução da associação, alguns empregados do Arsenal de Guerra acabaram processados criminalmente por vender, sem autorização oficial, bilhetes de rifas em benefício da Sociedade Bolsa de Caridade. ${ }^{11}$ Esse episódio levou à ruptura entre a direção do Arsenal e a Bolsa de Caridade. Ao saber do processo criminal envolvendo de alguma forma o nome do Arsenal de Guerra, o diretor expulsou a associação das suas dependências.

Então, a Sociedade passou a atuar na casa de associados, depois em sede alugada e em dezembro de 1879 aconteceu a primeira reforma nos seus estatutos, sendo retirado do título o termo "do Arsenal de Guerra da Bahia", passando a ser denominada apenas Sociedade Bolsa de Caridade. Na ocasião, a Sociedade deixou de ser exclusiva dos trabalhadores do Arsenal de Guerra da Bahia e passou a admitir "artistas" e profissionais brasileiros em geral. O seu artigo $3^{\circ}$ explicitava apenas que haveria duas classes de sócios - efetivos e honorários. Os sócios efetivos seriam os indivíduos nacionais, maiores de 18 anos de idade, de reconhecida "moralidade e qualidades" que exercessem "artes ou profissões". Os sócios honorários seriam os indivíduos que por sua "ilustração, posição e serviços" prestados à Sociedade merecessem essa distinção, mas apenas os sócios efetivos teriam direitos políticos. ${ }^{12}$ Não houve qualquer referência à situação das mulheres na associação. Portanto, apesar da abertura para trabalhadores de fora do Arsenal de Guerra, a reforma estatutária de 1879 não só manteve o "fechamento" para trabalhadores, como acrescentou a exigência de serem brasileiros.

Em 1892, foram aprovados os novos estatutos que ratificavam uma importante ampliação dos benefícios: o auxílio no valor de dez mil-réis para o sócio que enfermasse. Diferentemente dos regulamentos anteriores (1872 e 1879), este não explicitou a necessidade de se exercer "emprego, arte ou profissão" como condição para tornar-se sócio efetivo. O seu Art. $1^{\circ}$ estabelecia que a Sociedade "continua a ser composta de cidadãos brasileiros que, tendo um meio de vida honesta, a ela se queira agremiar". Apesar disso, permanecia nas entrelinhas a condição de associação mutual de trabalhadores. O seu Art. $7^{\circ}$ classificou os sócios como efetivos, honorários e beneméritos. O Art. 8ำ exigiu que o aspirante a sócio efetivo

11 O Monitor, Salvador, 15 de jul. 1877, p. 3.

12 ESTATUTOS da Sociedade Bosa de Caridade Reformados a 9 de Dezembro de 1879 e Instalada a 8 de Maio de 1872. Bahia: Litho-Typographia de J. G. Tourinho, 1880. p. 3-4. 
mencionasse nome, idade, estado, profissão e residência. O Art. 20 oferecia auxílio financeiro no caso de enfermidade que impossibilitasse o associado de trabalhar. ${ }^{13}$

Segundo Cláudia Viscardi, ainda que fossem agremiações de solidariedade horizontal "e definissem sua identidade a partir da isonomia e da ajuda mútua", as sociedades mutualistas tinham estruturas hierarquizadas e excludentes, sendo os fatores de exclusão mais usuais a renda ou profissão, o gênero, a idade e a nacionalidade. ${ }^{14}$ De início, a Sociedade Bolsa de Caridade incorporou quase todas essas modalidades de exclusão. Lembro ao leitor que, em seu primeiro Estatuto, a Associação era exclusiva para os trabalhadores do Arsenal de Guerra, podendo seus familiares participar apenas como beneficiários. Os Estatutos reformados de 1879 aceitavam como sócios apenas os trabalhadores nacionais maiores de 18 anos, sem fazer qualquer menção à situação das mulheres. Em 1892, os novos estatutos mantiveram a exclusão por nacionalidade, ampliaram a exclusão por faixa etária ao estabelecerem também a idade máxima (50 anos), criaram nova exclusão (gozar de perfeita saúde), permanecendo as mulheres sem direitos políticos e, dado importante, deixaram de exigir do aspirante a sócio o exercício de "artes ou profissões". Os Estatutos de 1900 não alteraram os fatores de exclusão, mas os de 1909 permitiram o ingresso de estrangeiros e garantiram às mulheres associadas os mesmos direitos conferidos aos homens, entretanto, só poderiam associar-se as esposas e filhas de sócios. ${ }^{15}$ Dado que a imigração europeia para a Bahia foi irrelevante, é possível que as restrições aos não brasileiros, explicitamente presentes nos estatutos de 1879, 1892 e 1900 e só excluídas na reforma estatutária de 1909, estivessem veladamente dirigidas aos africanos livres e libertos, hipótese não verificada em função da escassez de fontes.

De todo modo, o fato é que a associação foi lentamente eliminando algumas modalidades de exclusão ou fechamento. De uma associação exclusiva para artesãos e mestres de ofício do Arsenal de Guerra da Bahia ela passou a aceitar membros de posição indiferenciada do ponto de vista de classe, fossem brasileiros ou estrangeiros que tivessem entre 18 e 50 anos, o mesmo valendo para suas esposas e filhas, desde que gozassem de perfeita saúde e de reconhecida

13 ESTATUTOS e Regimento Interno da Sociedade Bolsa de Caridade Aprovados em Sessão de 23 de Março de 1892. Bahia: Tipografia do Diário da Bahia, 1892. p. 1-3.

14 VISCARDI, Cláudia Maria Ribeiro. Estratégias populares de sobrevivência: o mutualismo no Rio de Janeiro Republicano. Revista Brasileira de História, São Paulo, v. 29, n. 58, p. 297, 2009.

15 ESTATUTOS da Sociedade Bolsa de Caridade Aprovados em Sessão de 8 de Fevereiro de 1900. Bahia: Typographia Gutenberg, 1900; ESTATUTOS da Sociedade Bolsa de Caridade Aprovados em Sessão de Assembleia Geral de 24 de Março de 1909. Bahia: Tipografia e Encadernação do Lyceu de Artes, 1909. 
"moralidade" e idoneidade. Certamente, a necessidade de ampliação dos seus quadros por meio da adesão de novos sócios foi o principal motor para a eliminação de diversas modalidades de "fechamento", sendo mantidas apenas as exigências etárias, de saúde e moralidade. Entretanto, a abdicação de seu caráter de mutual exclusiva de trabalhadores não resultou em uma alteração significativa na composição do seu quadro de associados. Os artesãos e mestres de ofícios compuseram a base principal da organização no século XIX, passando a contar com o incremento da participação de trabalhadores menos qualificados no século XX.

À medida que a associação crescia e ampliava os benefícios aos sócios, também crescia o seu patrimônio físico. Em 1889, 17 anos após a sua fundação, a mutual adquiriu sua primeira sede própria: uma edificação à Rua do Gasômetro (localizada onde hoje é o bairro da Calçada, na Cidade Baixa). Em 1890, como já visto, passou a pagar o auxílio enfermidade e uma década depois, em dezembro de 1900, concluiu a construção de um mausoléu no cemitério da Quinta dos Lázaros. No final de 1913, a Sociedade Bolsa de Caridade adquiriu nova sede social, bem maior e mais bem localizada do que a primeira. A Sociedade Bolsa de Caridade gozou de saúde financeira durante todo o período pesquisado, sem dúvida uma das razões que explicam o sucesso dessa instituição, em que pese o recorrente e avultado número de inadimplentes e a manutenção de mensalidades e benefícios sem reajuste nas três primeiras décadas do século $X X$.

\section{A ocupação dos sócios}

Ainda que uma dada associação seja mais do que a soma dos seus sócios, para apreender sua dinâmica se faz necessário conhecer os atores sociais que se uniram para criá-la, que a dirigiram, que trabalharam para o seu êxito ou que simplesmente contassem estar relativamente protegidos ao ingressar numa das muitas sociedades mutualistas. Para tanto, busquei identificar a ocupação dos associados, tendo conseguido saber a ocupação de 288 sócios, ou seja, 13,3\% da listagem nominal de 2.172 filiados de ambos os sexos.

Para facilitar a leitura e a análise dos dados, agrupei esses profissionais em categorias. No Gráfico 1, as categorias profissionais foram agrupadas por números absolutos e por percentuais. 


\section{Gráfico 1}

Profissões agrupadas por categoria ocupacional em números absolutos e em percentual (1872-1930).

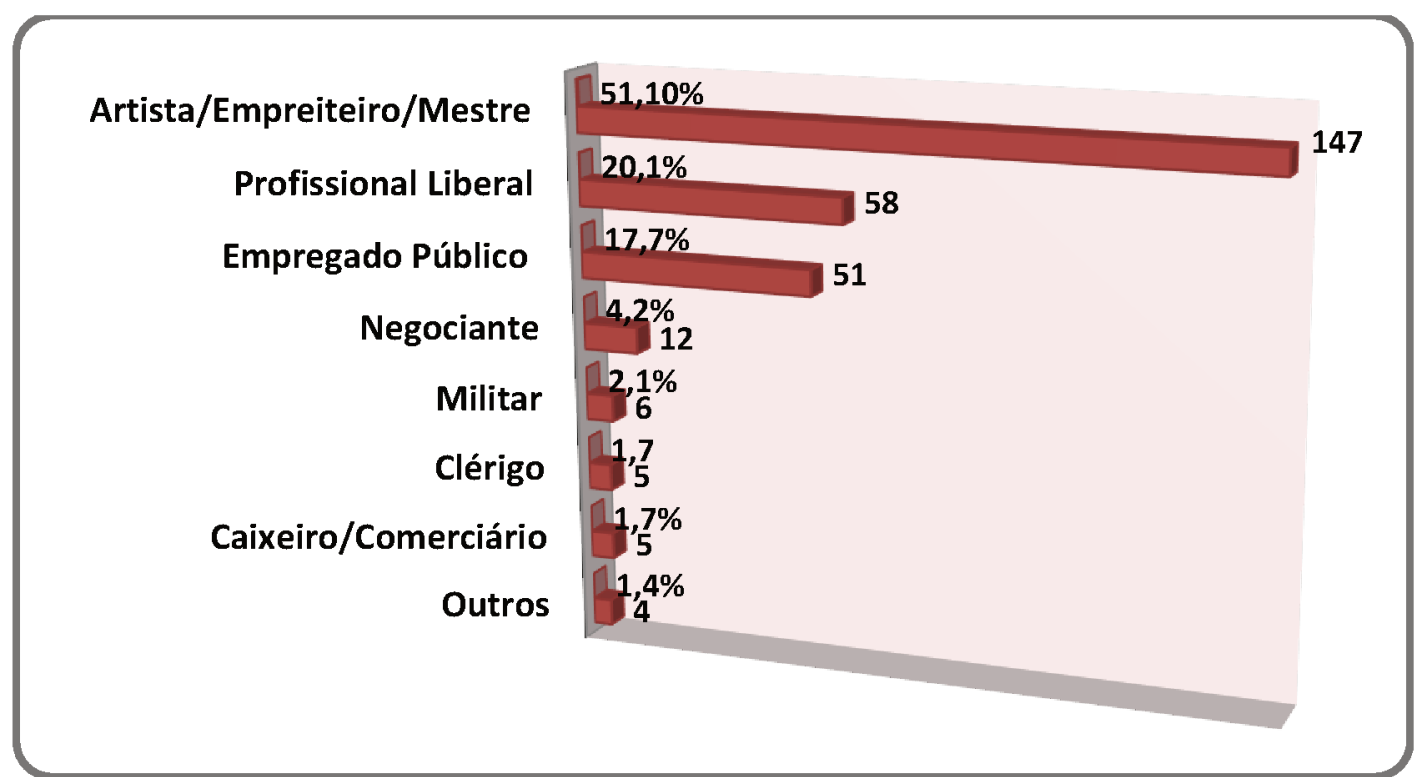

Fontes: APEB. Seção Judiciária, Inventários e Testamentos; Necrológicos; Estatutos e Relatórios da Sociedade Bolsa de Caridade; Jornais e Almanaques. Legenda: *Outros: um lavrador e três cabeleireiros.

Como pode ser observado, o grupo de artesãos, empreiteiros e mestres de ofício era o majoritário entre os associados da Bolsa de Caridade e contava com pelo menos 147 indivíduos, o que correspondia a 51,1\% da amostragem. Por artesão, artífice ou artista entenda-se o conjunto formado pelos trabalhadores qualificados, que podiam ou não ser proprietários, no todo ou em parte, dos seus instrumentos de trabalho e/ou oficinas. A título de exemplo, podemos citar alfaiates, marceneiros, carapinas, pedreiros, sapateiros, ferreiros, carpinteiros, tipógrafos, pintores, entre outros. Na tentativa de resistir ao processo de proletarização completa, os artistas buscaram meios de não serem confundidos com os operários. Para tanto, fundavam associações e buscavam valorizar a arte, a maestria, a qualidade, o compromisso, a honestidade, a criatividade, o orgulho do seu ofício, enfim, tudo o que pudesse diferenciá-los dos operários fabris. Segundo Claudio Batalha, o discurso de nobilitação do trabalho ocupou um lugar central na linguagem das sociedades mutualistas e foi precursor de um discurso classista. ${ }^{16}$ Adiante, quando discorro sobre a rede de relações dos membros dessa associação, o leitor vai conhecer alguns desses trabalhadores.

16 BATALHA, Claudio H. M. Sociedades de trabalhadores no Rio de Janeiro do século XIX: algumas reflexões em torno da formação da classe operária. Cadernos AEL, Campinas, v. 6, n. $10 / 11$, p. $42-67,1999$. 
De acordo com o Gráfico 1, 58 profissionais liberais compunham o segundo maior grupo da associação, o que correspondia a 20,1\% da amostra. ${ }^{17}$ Exceto parte dos professores, não me parece que os demais profissionais liberais buscassem essa sociedade de ajuda mútua com vistas a um possível socorro. Afinal, bacharéis, médicos, engenheiros e dentistas dificilmente teriam o mesmo status ou estariam no mesmo patamar socioeconômico de artífices e de pequenos funcionários públicos. $O$ mais provável é que esses profissionais integrassem a parcela de associados que poderia facilitar o trânsito das demandas da agremiação junto às esferas de poder. De todo modo, em razão do pequeno percentual desta amostra - apenas 13,3\% do total de associados - esse número pode estar superestimado, posto ser mais comum encontrar os registros ocupacionais dessa categoria profissional em comparação com trabalhadores pobres, provável maioria das centenas de membros dos quais não consegui identificar a ocupação.

Entre os 58 profissionais liberais, havia 13 médicos, 7 farmacêuticos, 17 professores, 6 engenheiros, 4 dentistas, 6 bacharéis, 3 administradores, 1 jornalista e um foi identificado apenas como "doutor". A soma dos 13 médicos com os 7 farmacêuticos e os 4 dentistas resultou em um total de 24 profissionais liberais da área da saúde, setor muito mal servido pelo poder público, portanto, muito importante para a organização operária. Pelo menos 7 médicos prestaram serviços gratuitos à associação, 3 foram membros de sua diretoria e 5 exerceram cargos públicos. A prestação de serviços médicos gratuitos aos membros associados comumente era retribuída na forma de votos nas eleições, sendo esta uma demonstração trivial do funcionamento do clientelismo no seio das mutuais. Para ficar apenas em um exemplo, cito o caso do sócio benemérito Manoel Pereira Espinheira, médico substituto do Hospital da Quinta dos Lázaros, que tinha consultório próprio em Água de Meninos, onde atendia os associados da SBC. Em fevereiro de 1890, quase um ano antes de lançar sua candidatura a deputado, ofereceu-se para tratar gratuitamente dos consórcios enfermos, o que fez por mais de 20 anos, a ponto de ter sido citado nos relatórios de 1913 e 1922 como pessoa dedicada ao engrandecimento da associação. ${ }^{18}$

Os 17 professores da amostra formavam um grupo bastante heterogêneo que abrigava do professor primário ao do ensino superior, sendo a diferença de estratificação de renda e status social bastante significativa, assim como a motivação para associar-se à Bolsa de Caridade. Embora a condição do professor público

17 A definição de profissional liberal, usada na presente pesquisa, diz respeito ao profissional, usualmente com formação universitária, que tem liberdade para executar a sua atividade, podendo ser empregado ou trabalhar por conta própria.

18 Pequeno Jornal, Salvador, 23 jan. 1891. p. 2. 
primário fosse bastante precária, alguns profissionais conseguiram se destacar, a exemplo do professor municipal Presciliano José Leal (Figura 3), que foi presidente do Diretório da SBC, entre 1897 e 1898, ministrou aulas como professor primário no Distrito dos Mares e também exerceu a função de 1ํㅡㄹ Delegado Escolar entre $1905 \mathrm{e}$ 1915. ${ }^{19}$ Foi o caso do professor Antônio Bahia da Silva Araujo. O professor Bahia assumiu as aulas públicas da freguesia da Sé em 1870 e, em 1881, encontrava-se ministrando aulas de Pedagogia na Escola Normal de Homens, instituição que formava professores primários. ${ }^{20}$ Antônio Bahia foi deputado em várias legislaturas, tanto no Império, quanto na República, sendo um dos responsáveis pela concessão da subvenção estatal para a Bolsa de Caridade em 1888, ainda no Império. A trajetória desse professor também é ilustrativa do como se davam as relações clientelistas no seio das associações de ajuda mútua.

O terceiro maior grupo era composto por 51 empregados em órgãos públicos, $17,7 \%$ dos membros da amostra. A maior parte trabalhava como contínuo, escrevente, carteiro, porteiro ${ }^{21}$, oficial ou motorista. Vê-se que grande parte desse grupo era constituída por trabalhadores de baixo poder aquisitivo, mesmo os que integravam o quadro permanente do funcionalismo público. Apesar de esses trabalhadores estarem empregados em órgãos governamentais, nem todos eram funcionários públicos, uma vez que podia variar a relação jurídica existente entre as diversas categorias de indivíduos que prestavam serviços públicos e o Estado. Segundo Tania de Luca, "A legislação referente ao funcionalismo durante o período compreendido entre 1889 e 1935 pode ser caracterizada como um emaranhado de leis, decretos e regulamentos, nem sempre harmônicos. ${ }^{22}$ Os empregados civis do Arsenal de Guerra, por exemplo, podiam ser dispensados a qualquer tempo, como efetivamente acontecia, sendo grande parte constituída de indivíduos contratados por empreitada ou jornaleiros. Entretanto, na falta de opção melhor, classifiquei os trabalhadores dos setores burocráticos do Arsenal na categoria de empregados públicos.

19 RELATÓRIO do Exercício de 1897 a 1898 Apresentado em Assembleia Geral da Socidade Bolsa de Caridade pelo Presidente do Diretório Presciliano José Leal na Sessão Magna de 5 de Junho de 1898 Comemorativa do 26 Aniversário. Bahia: Litho-Typo. e Encadernação V. Oliveira \& C., 1898; Gazeta De Notícias, Salvador, 23 dez. 1912.

20 RELATÓRIO dos Trabalhos do Conselho Interino do Governo (BA) - 1823 a 1889. Ano 1879, p. 188.

21 O cargo de porteiro não se referia à incumbência de atendimento da entrada de um prédio, hotel ou qualquer instituição. A Lei n. 628, de 14 de setembro de 1905, que reorganizou o serviço sanitário do Estado da Bahia, em seu Art. 25 estabeleceu: "Ao porteiro, que tem como auxiliares o contínuo, o carteiro e os serventes, cumpre: 1‥ Abrir e fechar a repartição. 2o Velar pelo asseio interno e externo do edifício da repartição. 3. Fechar e expedir correspondências. 4.. Ter sob sua guarda o Livro da Porta, no qual deverá lançar o resumo dos papéis e, na íntegra, os despachos proferidos. 5. Escrever o protocolo da entrada e saída de toda correspondência."

22 LUCA, op. cit., p. 108-109. 
Outro grupo de alguma expressão identificado no Gráfico 1 foi o dos negociantes - eles representavam 4,2\% da amostra. Quase metade participou da administração da Bolsa de Caridade, ou seja, 5 do total de 12 comerciantes. Quatro deles fizeram parte da administração de outras sociedades de ajuda mútua. Era um grupo heterogêneo, formado por pequenos e médios negociantes. Ao morrer, a maioria deixou apenas a casa de residência, geralmente modesta.

Enfim, da análise do Gráfico 1 infere-se que, apesar de a Sociedade Bolsa de Caridade admitir indivíduos de diversas camadas sociais, era uma agremiação formada majoritariamente por trabalhadores. A soma dos dois grupos que englobava, em sua maioria, trabalhadores (artesãos, empreiteiros de obras e mestres de ofício e empregados públicos) representava $69 \%$ da composição social da agremiação. Eram trabalhadores que se distinguiam da massa operária pela qualificação profissional, caso dos "artistas", ou pelo grau de alfabetização necessário ao exercício de variadas funções no serviço público, a exemplo de escreventes, escriturários, amanuenses, oficiais, carteiros, entre outras. É preciso frisar também que, provavelmente, parte significativa dos sócios, cuja ocupação não foi identificada, era formada por trabalhadores, hipótese que me faz sustentar que o peso do mundo do trabalho na Bolsa de Caridade era bem maior.

\section{A cor dos trabalhadores}

Dos 2.172 sócios nominalmente listados nos relatórios da Sociedade Bolsa de Caridade, foi possível identificar a cor de 103 deles, o que representa $4,7 \%$ do total de associados, ao longo do recorte desta pesquisa. Desses, 24 indivíduos foram classificados como brancos, 57 como pretos e 22 como mestiços, ou seja, 79 membros da SBC eram negros ou mestiços, o que resulta em um percentual de $77 \%$ de não brancos e $23 \%$ de brancos, conforme se pode observar no Gráfico 2.

\section{Gráfico 2}

Composição por cor dos membros da SBC (1872-1930).

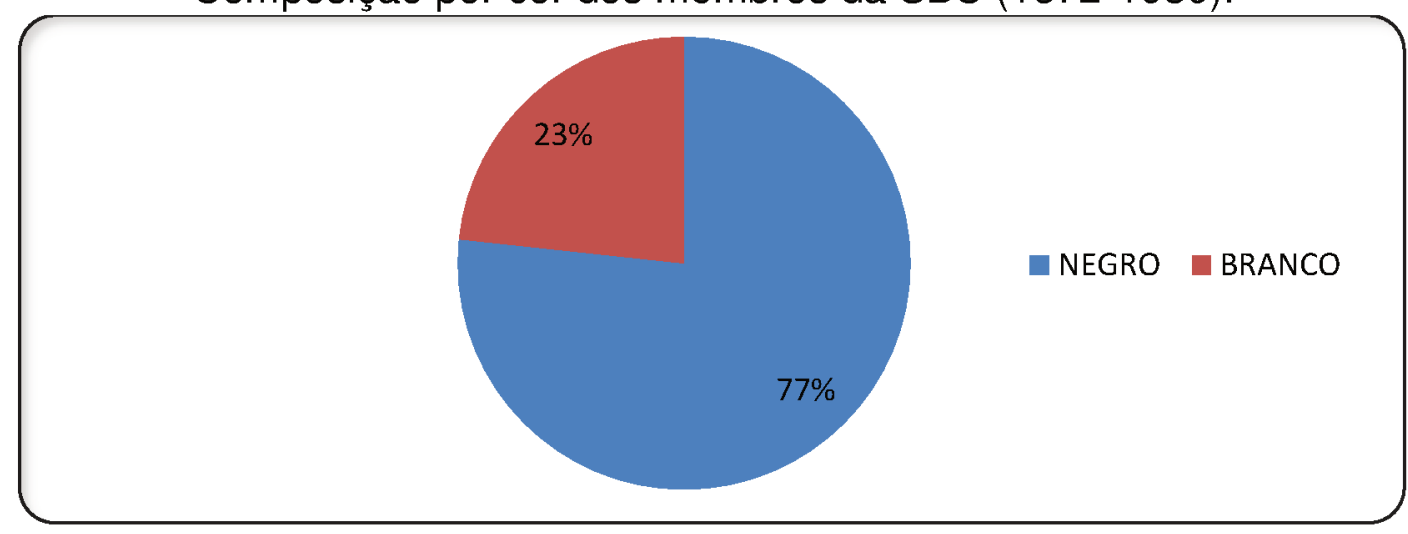

Fontes: APEB. Seção Judiciária. Inventários e Testamentos e Necrológicos. 
O percentual encontrado no Gráfico 2 se aproxima da composição da população de Salvador do período. ${ }^{23}$ Entretanto, se fossem retirados dessa amostragem apenas cinco associados - os médicos brancos que prestaram serviços voluntários à agremiação - o percentual de brancos cairia de $24 \%$ para $18 \%$. Apesar do pequeno tamanho da amostra, esses números coincidem com os encontrados por Aldrin Castellucci para outra importante associação do período, o Centro Operário da Bahia, instituição que abrigava grande quantidade de trabalhadores alfabetizados e qualificados e que tinha seus quadros compostos por $77,1 \%$ de pretos, pardos ou mestiços. Segundo o autor, a trajetória dos membros da associação demonstrou o prestígio social alcançado por muitos deles, o que relativiza a tese da total marginalização da população negro-mestiça após a abolição. ${ }^{24}$

\section{Tabela 1}

Ocupação dos membros brancos e não brancos da SBC (1872-1930)

\begin{tabular}{lcc}
\hline Profissão & Brancos & Não brancos \\
\hline Artesão e mestre de ofício & $28 \%$ & $79 \%$ \\
\hline Empregado Público & $5 \%$ & $\mathbf{8 \%}$ \\
\hline Profissional Liberal & $38 \%$ & $6 \%$ \\
\hline Empresário * & $14 \%$ & $3 \%$ \\
\hline Outro $^{\star *}$ & $15 \%$ & $\mathbf{4 \%}$ \\
\hline Total da amostra & $\mathbf{1 0 0 \%}$ & $\mathbf{1 0 0 \%}$ \\
\hline Fontes: APEB. Seção Judiciária, Inventários e Testamentos e Necrológicos. \\
Legenda: * Negociante, comerciante e industrial. ${ }^{* *}$ Caixeiro, cabeleireiro, cônego e militar
\end{tabular}

As fontes consultadas possibilitaram associar cor com profissão para 86 associados, o que corresponde a $4 \%$ do total de associados da Bolsa de Caridade, ao longo do período pesquisado. A Tabela 1 indica que, entre os brancos, o peso maior é dos profissionais liberais (38\%), seguido dos artesãos e mestres de ofício (28\%) e dos negociantes (14\%). Já entre os não brancos, os artesãos e mestres de ofício são a imensa maioria (79\%); somado aos empregados públicos, o índice de trabalhadores seria de $33 \%$ para os brancos e de $87 \%$ para os pretos e mestiços. Apenas 6\% dos não brancos da associação são profissionais liberais, enquanto entre os brancos esse índice sobe para 38\%, sendo a maioria formada por médicos. Esses dados indicam o predomínio de brancos nas ocupações de maior prestígio social e melhor remuneração entre os membros da associação objeto deste estudo.

23 O Censo demográfico de 1940 indicou que os não brancos constituíam $66,2 \%$ da população de Salvador, percentual muito próximo do apontado pelos dados do Recenseamento de 1872 (68,9\%). BACELAR, Jeferson. Os negros em Salvador: os atalhos raciais. Revista de História, São Paulo, n. 129-131, p. 53-65, 1993/1994.

24 CASTELLUCCI, Aldrin Armstrong Silva. Trabalhadores e política no Brasil: do aprendizado do Império aos sucessos da Primeira República. Salvador: EDUNEB, 2015. Sugere-se, principalmente, a leitura do capítulo 3. 
Grande parte dos brancos dessa amostragem estava longe da situação de vulnerabilidade, que levava os trabalhadores a buscar as associações de auxíliomútuo como única alternativa para escapar do descenso social e da caridade pública, em momentos de doença, desemprego ou morte. Metade desse grupo era formada por profissionais liberais e negociantes. Os inventários e testamentos desse grupo demonstraram não ser incomum que seus membros possuíssem patrimônio ou status social condizentes com os da classe média.

Entre os mestiços, havia certo equilíbrio entre as camadas sociais, levando em consideração apenas o quesito ocupação. Dos 16 sócios cuja ocupação foi revelada, 8 eram artífices, 4 empregados públicos, 2 profissionais liberais (um médico e um bacharel, por sinal irmãos), 1 caixeiro e 1 abastado comerciante. E dos 57 sócios de cor preta, consegui identificar a profissão de 50 deles: 44 eram artesãos e mestres de ofício, sendo 2 deles também "empresários". Não era incomum que "artistas" ascendessem à condição de "empresários", posto que muitos já dispunham de suas próprias oficinas. Um exemplo é o de Francisco Luiz de Azevedo, ferreiro mestiço, falecido aos 69 anos, em 1913, quando já era viúvo. Entre os bens inventariados, constava um sobrado de dois pavimentos com os respectivos maquinários da fundição de ferro, situado no Largo do Pilar. ${ }^{25}$

Ainda que a amostra obtida para o critério cor da pele indique que $79 \%$ dos não brancos eram "artistas", havia diferença entre pretos e mestiços. Enquanto $88 \%$ dos pretos eram artistas, entre os mestiços esse índice caía para 50\%.

\section{A rede de relações sociais}

Entre 1872 e 1930, o total de associados da Sociedade Bolsa de Caridade chegava a 2.351. As fontes permitiram identificar os nomes de 2.172 deles, número adotado como parâmetro no presente trabalho. Desse total, 224 filiados integraram a administração de outras associações de ajuda mútua. Isso significa que 10,3\% da listagem nominal dos associados da SBC não apenas faziam parte de outras associações, como também integravam os seus corpos diretivos. Se for levado em conta o pequeno número de associados que frequentava as assembleias gerais, é possível afirmar que esse é um número bastante significativo.

25 APEB. Seção Judiciária, 1/387/747/10. Autos Cíveis - Inventários e Testamentos. 


\section{Quadro 1}

Participação de membros da SBC na direção de outras mutuais (1872-1930).

\begin{tabular}{|c|c|c|c|c|}
\hline & NOME DA SOCIEDADE MUTUALISTA & 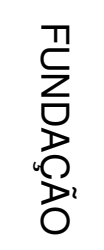 & 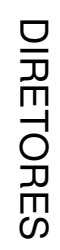 & 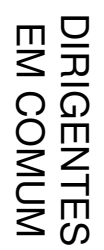 \\
\hline 1 & Centro Operário da Bahia & 1894 & 50 & 10 \\
\hline 2 & Sociedade Protetora dos Desvalidos & 1851 & 42 & 6 \\
\hline 3 & Sociedade Beneficente Bolsa dos Patriotas & 1895 & 39 & 17 \\
\hline 4 & Soc. Beneficente União Filantrópica dos Artistas & 1889 & 31 & 10 \\
\hline 5 & Sociedade Montepio dos Artífices da Bahia & 1832 & 22 & 8 \\
\hline 6 & Sociedade Beneficente de Santana & 1896 & 20 & 3 \\
\hline 7 & Associação Typográphica Bahiana & 1871 & 15 & 6 \\
\hline 8 & Sociedade Beneficente dos Alfaiates & 1897 & 12 & 3 \\
\hline 9 & Sociedade Beneficente União das Classes & 1895 & 11 & 4 \\
\hline 10 & Club Beneficente dos Martyres & 1891 & 10 & 2 \\
\hline 11 & Sociedade Beneficente União e Amparo & & 10 & 4 \\
\hline 12 & Sociedade Beneficente dos Açougueiros & & 8 & 3 \\
\hline 13 & Sociedade Montepio dos Artistas da Bahia & 1853 & 8 & - \\
\hline 14 & Congresso Beneficente Auxílio Fraternal & 1898 & 6 & 1 \\
\hline 15 & Sociedade Beneficente dos Marceneiros & & 6 & 1 \\
\hline 16 & Club Defensor e Beneficente dos Maquinistas & 1889 & 5 & - \\
\hline 17 & Sociedade Dezesseis de Julho & 1906 & 5 & 4 \\
\hline 18 & Sociedade Beneficente Bolsa dos Chapeleiros & 1891 & 4 & 1 \\
\hline 19 & Grêmio Beneficente do Professorado Baiano & 1898 & 3 & 1 \\
\hline 20 & Sociedade Beneficência Mútua de Brotas & 1893 & 3 & - \\
\hline 21 & Sociedade Beneficência $1 \stackrel{\circ}{\circ}$ de Maio & 1894 & 3 & - \\
\hline 22 & Congresso Beneficente Auxílio Funeral & & 2 & 1 \\
\hline 23 & Sociedade Humanitária dos Artistas & 1856 & 2 & 2 \\
\hline 24 & Soc. Protetora e Beneficente dos Artífices, Carpinteiros & 1860 & 2 & 2 \\
\hline 25 & Sociedade Beneficente de Socorros Mútuos & 1897 & 1 & - \\
\hline 26 & Sociedade Beneficente Telegráfica & 1898 & 1 & - \\
\hline 27 & Sociedade Beneficente dos Funcionários Públicos & 1887 & 1 & 1 \\
\hline 28 & Sociedade Beneficente 24 de Julho & 1909 & 1 & - \\
\hline 29 & Sociedade Montepio da Bahia & & 1 & - \\
\hline 30 & Club União dos Artistas Republicanos & 1890 & 1 & - \\
\hline
\end{tabular}

Fontes: APEB. Biblioteca Francisco Vicente Vianna. Relatórios. Caixa 60, Estatutos e relatórios da SBC. BIBLIOTECA PÚBLICA DO ESTADO DA BAHIA. Seção de Obras Raras. Relatórios institucionais, jornais e almanaques. 
O Quadro 1 permite a observação dessa rede associativa sob uma perspectiva mais específica: a da participação dos associados da Bolsa de Caridade nos quadros administrativos de 30 sociedades de ajuda mútua. O Centro Operário da Bahia foi a instituição que mais contou com membros da Sociedade Bolsa de Caridade entre os seus dirigentes. Segundo Aldrin Castellucci, o Centro Operário foi uma máquina política que, nos anos iniciais da República, conseguiu mobilizar politicamente a classe operária em torno das lutas por direitos, de modo eficiente, inclusive elegendo vários dos seus integrantes como Juiz de Paz, para as Juntas Distritais e o Conselho Municipal de Salvador. ${ }^{26} \mathrm{O}$ fato de o Centro Operário, associação de ajuda mútua com ampla atuação na esfera político-eleitoral, ter tido entre seus dirigentes 50 associados de uma agremiação cujo objetivo exclusivo era o dos socorros mútuos, como foi o caso da Bolsa de Caridade, sugere que os trabalhadores poderiam filiarse a mais de uma mutual, visando objetivos diversos, para além dos benefícios previdenciários. Para os trabalhadores que contavam com renda suficiente para filiarse a várias mutuais, concomitantemente, é provável que garantir benefícios maiores fosse um fator importante. Entretanto, o grande número de dirigentes do Centro Operário, que também integrava o quadro social da SBC, é um indício da importância do associativismo operário na interlocução política e como representante dos interesses do conjunto dos trabalhadores. Eles certamente almejavam a extensão e ampliação dos direitos de cidadania para os trabalhadores e a valorização de ofícios, categorias profissionais ou dos trabalhadores na sua condição de classe social. Embora a Bolsa de Caridade não fosse um espaço institucional que se propusesse a agir em defesa da ampliação dos direitos do conjunto dos trabalhadores, parte dos seus membros desempenhava essa função, como demonstra sua atuação na direção do Centro Operário da Bahia. ${ }^{27}$

A Sociedade Protetora dos Desvalidos (SPD), fundada em 1851, foi a segunda mutual em número de dirigentes que também eram associados à SBC. ${ }^{28}$ Dos 42 dirigentes da agremiação, que também eram sócios da SBC, 6 integraram o corpo administrativo das duas associações. Foi o caso de Júlio Alves da Palma, mecânico

26 CASTELLUCCI, 2015, op. cit., p. 113.

27 Sobre os sucessos eleitorais dos membros do Centro Operário da Bahia, cf. CASTELlUCCI, Aldrin A. S. Política e cidadania operária em Salvador (1890-1919). Revista de História (USP), São Paulo, n 162, p. 205-241, 1ํ semestre 2010.

28 A SPD foi fundada em 1851 por um grupo de associados saídos da Irmandade de Nossa Senhora da Soledade Amparo dos Desvalidos, que havia sido criada em 1832. Ambas as associações admitiam apenas homens de cor preta em seus quadros. Sobre esse processo, cf. LEITE, op. cit.; CAMPOS, Lucas Ribeiro. Sociedade Protetora dos Desvalidos: mutualismo, política e identidade racial em Salvador (1861-1894). 2018. Dissertação (Mestrado em História), Universidade Federal da Bahia, 2018. 
da Oficina da Assistência Pública que, além de exercer diversos cargos na Sociedade Protetora dos Desvalidos, entre 1898 e 191929, foi dirigente de mais quatro sociedades mutualistas, incluindo a Sociedade Bolsa de Caridade. Também foi o caso do $2^{\circ}$ escriturário da Diretoria de Higiene Municipal, Florencio da Silva Friandes (Figura 2). ${ }^{30}$ Além de conselheiro consultivo permanente da Sociedade Protetora dos Desvalidos e de atuar no diretório da Sociedade Bolsa de Caridade por mais de 15 anos consecutivos, ele ainda fez parte da administração da Sociedade Dezesseis de Julho, ${ }^{31}$ da Sociedade Beneficente dos Açougueiros ${ }^{32}$ e da Sociedade Beneficente União e Amparo. ${ }^{33}$

A Sociedade Beneficente Bolsa dos Patriotas contou com 39 dirigentes, que também eram membros da Sociedade Bolsa de Caridade, sendo a terceira associação do Quadro 1. Foi a mutual com maior número de dirigentes em comum: 17 deles compuseram os quadros diretivos de ambas as associações. A proximidade entre essas duas associações pode ser observada pelo fato de a Sociedade Bolsa de Caridade ter disponibilizado, em 28 de julho de 1915, um crédito hipotecário no valor de 3:500\$000 (três contos e quinhentos mil réis), a ser amortizado "conforme as forças" da "coirmã" Sociedade Bolsa dos Patriotas. ${ }^{34}$ Outro dado que comprova a proximidade entre as duas associações é a composição do quadro administrativo da Sociedade Bolsa dos Patriotas, no exercício de 1924/1925, quando quase toda a diretoria da Bolsa dos Patriotas era composta por membros da Bolsa de Caridade. ${ }^{35}$

29 RELATÓRIO da Sociedade Protetora dos Desvalidos Relativo ao Exercício de 1895 a 1896, Apresentado pelo Presidente do Diretório, Florencio da Silva Friandes, Aprovado em Sessão de 23 de Outubro de 1896. Bahia: Imprensa Moderna de Prudencio de Carvalho, 1896; RELATÓRIO da Sociedade Protetora dos Desvalidos Relativo ao Exercício de 1896 a 1897, Apresentado pelo Presidente do Diretório, João Francisco Regis d'Antão, Aprovado em Sessão de 1 de Novembro de 1897. Bahia: Imprensa Moderna de Prudencio de Carvalho, 1897; RELATÓRIO da Sociedade Protetora dos Desvalidos Relativo ao Exercício de 1899 a 1900, Apresentado pelo Presidente do Diretório, Affonso Maria João de Freitas, Aprovado em Assembleia Geral de 5 de janeiro de 1901. Bahia: Imprensa Moderna de Prudencio de Carvalho, 1900; RELATÓRIO da Sociedade Protetora dos Desvalidos, Apresentado pelo Presidente do Diretório, Julio Alves da Palma, Aprovado em Sessão d'Assembleia Geral de 24 de Outubro de 1919. Exercício de 1918-1919. Bahia: Tipografia e Encadernação do Liceu de Artes e Ofícios, 1919.

30 ANNUARIO Administrativo, Agrícola, Profissional, Mercantil e Industrial da República dos Estados Unidos do Brasil para 1917. Rio de Janeiro: Almanak Laemmert, 1917. p. 71.

31 A Notícia, Salvador, 8 mar. 1915, p. 2

32 O Imparcial, Salvador, 12 jan. 1935, p. 2.

33 Gazeta de Notícias, Salvador, 7 nov. 1913, p. 3.

34 RELATÓRIO Sociedade Bolsa de Caridade Exercício de 1915 a 1916. Apresentado pelo Presidente do Diretório J. Prudencio F. de Carvalho em Assembleia Geral Realizada em 7 de Julho de 1916 e Unanimemente Aprovado. Bahia: Tipografia e Encadernação do Liceu de Artes e Ofícios, 1916.

35 RELATÓRIO Sociedade Beneficente Bolsa dos Patriotas Apresentado pelo Presidente do Conselho Diretório Joaquim da Costa Dória em Sessão da Assembleia Geral de 29 de 
A Sociedade Beneficente União Philantrópica dos Artistas foi a quarta mutual em número de dirigentes associados da Bolsa de Caridade, 31. Desses, 10 dirigiram ambas as sociedades mutualistas. No seu corpo diretivo, há um caso emblemático do quanto as associações de trabalhadores podiam favorecer os seus dirigentes. Trata-se do Tenente-coronel, Juiz de Paz e armador João Pedro Rodrigues Lima. Esse artesão foi tesoureiro da Irmandade de N. S. da Fé ${ }^{36}$ e da Confraria de N. S. do Rosário dos Quinze Mistérios. ${ }^{37}$ Também exerceu cargos em pelo menos sete associações de ajuda mútua, entre 1898 e 1917, ano em que faleceu. De início, atendia seus clientes em uma loja na Ladeira do Taboão ${ }^{38}$, depois montou uma casa de armador no Pelourinho. ${ }^{39}$ As irmandades e as associações de ajuda mútua eram suas clientes potenciais e tudo indica que ele não via problemas em prestar serviços a associações das quais fazia parte como membro do corpo dirigente. Foi Rodrigues Lima, como presidente da Assembleia Geral do Centro Operário da Bahia ${ }^{40}$, por exemplo, quem montou toda a ornamentação da solenidade organizada pelo Centro Operário da Bahia por ocasião do $7^{0}$ dia do falecimento de d. Orsina da Fonseca, esposa do marechal Hermes da Fonseca, presidente da República.

Além dos benefícios financeiros, João Pedro Rodrigues Lima contava com o apoio dessas associações para pleitear cargos eletivos no âmbito municipal, tendo sido eleito Juiz de Paz pelo distrito do Paço, em 191441, e candidato ao Conselho Municipal, em 1915. Foi o Centro Operário que apresentou a sua candidatura ao Conselho Municipal, fazendo um apelo aos operários para que elegessem um representante da classe trabalhadora:

Operários!
Mandamos sempre para as assembleias populares
representantes de outras classes médicos, bacharéis, capitalistas,
etc. - por que, pois para o Conselho Municipal, a mais popular de
todas elas não enviamos um mandatário nosso, lídimo
representante nosso, enfim um operário como nós? ${ }^{42}$

Pelo visto ele não era um simples operário, como consta no anúncio. Além de ser um trabalhador qualificado, tinha o seu próprio negócio e, provavelmente, contava

Outubro de 1925 e na Mesma Aprovado. Bahia: Tipografia e Encadernação do Liceu de Artes e Ofícios, 1925.

36 A Notícia, Salvador, 29 maio 1915, p. 3.

7 A Notícia, Salvador, 23 fev. 1915, p. 3.

38 Leituras Religiosas, Salvador, 19 out. 1902, p. 7.

39 A Notícia, Salvador, 21 dez. 1914, p. 1.

40 Gazeta de Notícias, Salvador, 6 dez. 1912, p. 2.

41 Gazeta de Notícias, Salvador, 29 jan. 1914, p. 1.

42 A Notícia, Salvador, 11 nov. 1915, p. 2. 
com outros trabalhadores a seu serviço. Ou talvez o eleitorado que ele pretendia atingir era o dos operários qualificados e pequenos funcionários públicos, justamente a parcela da classe trabalhadora alfabetizada que estava apta a votar nas eleições municipais e que era a base das associações de ajuda mútua. Porém, apesar do apoio da máquina eleitoral do Centro Operário e de participar da direção de tantas mutuais, sua candidatura não logrou êxito. Seja como for, suas relações com o associativismo indicam que os cargos ocupados nas irmandades e associações de ajuda mútua de trabalhadores poderiam proporcionar não apenas votos, mas também se configurar como uma fonte de renda.

Fundada em 1832, a Sociedade Monte Pio dos Artífices da Bahia estava entre as mais antigas mutuais da Província. Essa associação teve entre seus dirigentes 22 associados da Bolsa de Caridade, a exemplo do mestiço Francisco Andrelino Brandão de Araújo. Francisco era empregado público e exerceu a função de visitador na SBC, entre 1910 e 1913. Ao morrer, em 1927, deixou para os herdeiros, sua esposa e um filho de 16 anos, apenas uma caderneta de poupança na Caixa Econômica Federal, no valor de 668 mil e 720 réis. ${ }^{43}$ Apesar disso, não deve ter tido problemas financeiros para seu enterramento, uma vez que era dirigente de quatro associações de ajuda mútua: Monte Pio dos Artífices, Bolsa de Caridade, Bolsa dos Patriotas e Associação Tipográfica.

A Sociedade Beneficente de Santana teve entre seus dirigentes 20 associados da Bolsa de Caridade, sendo três deles diretores de ambas as associações. Como pode ser visto no Quadro 1, foi a sexta agremiação com maior número de associados da Bolsa de Caridade em sua administração. Um dos seus diretores foi o tipógrafo branco José Bernardo da Cunha, falecido em abril de 1901, aos 41 anos. O falecido deixou apenas três pequenas casas no bairro do Rio Vermelho, todas hipotecadas a Carolino José Barroso de Mello, pela quantia de 5 mil contos de réis. ${ }^{44}$ Apesar disso, esse "artista" certamente conseguiu manter um padrão de vida acima da média da classe operária.

A Associação Tipográfica Baiana, fundada em 16 de abril de 1871, era uma associação de auxílio-mútuo que congregava tipógrafos, litógrafos ou livreiros. Era, portanto, uma agremiação profissional de ajuda mútua, com forte probabilidade de ter atuado na defesa da categoria em outras esferas que não a previdenciária. $O$ tipógrafo José Prudencio Ferreira de Carvalho (Figura 1), filiado desde 1888, ocupou diversos cargos na associação, sendo uma de suas lideranças. Ele inclusive dirigiu

${ }^{43}$ APEB. Seção Judiciária, 6/2270/2770/6. Autos Cíveis - Inventários e Testamentos.

${ }^{44}$ APEB. Seção Judiciária, 1/80/110/4. Autos Cíveis - Inventários e Testamentos. 
as duas associações concomitantemente, sendo um dos 15 associados da SBC que ocuparam cargos na Associação Tipográfica Baiana.
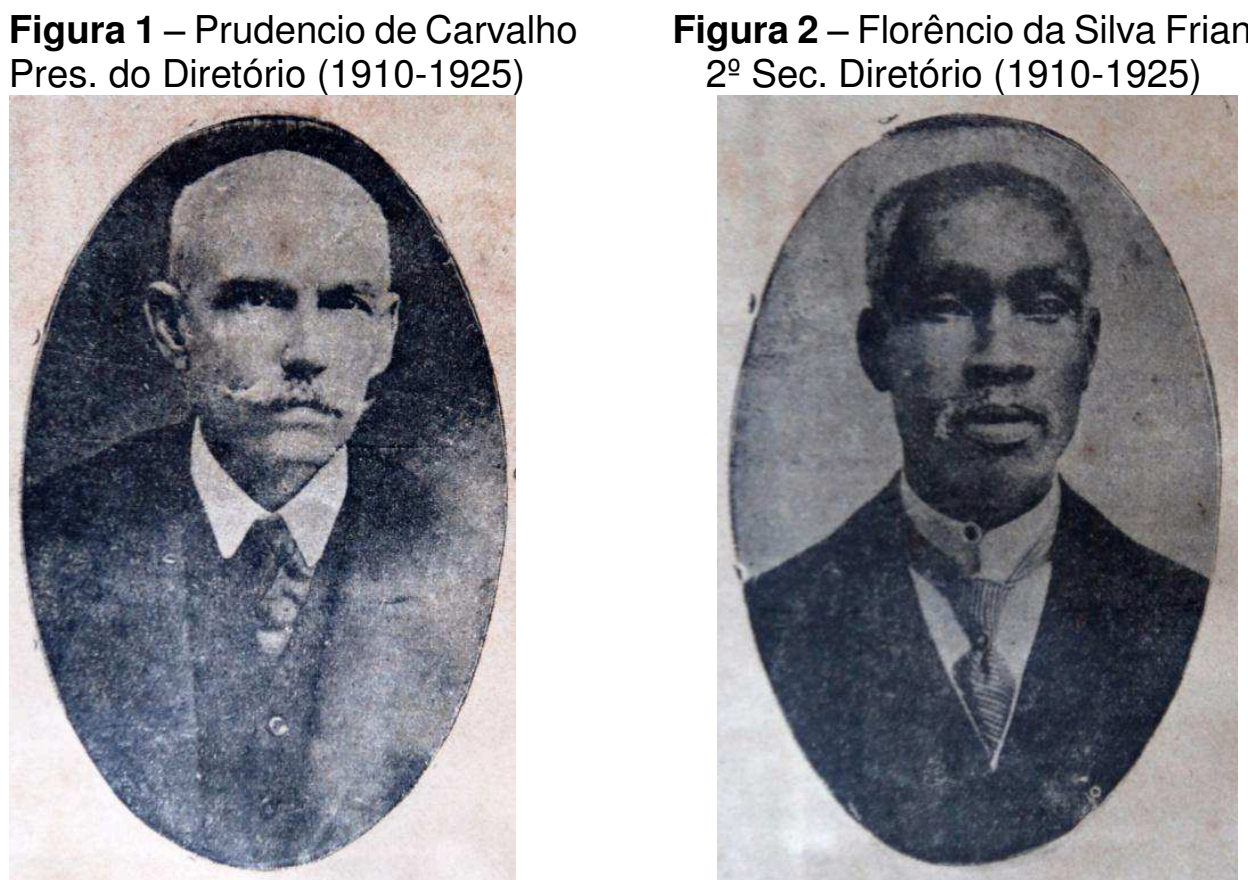

Fonte: Relatório da Sociedade Bolsa de Caridade - Cinquenta anos de existência. 1872-1922, Bahia: 1922; APEB. Biblioteca Francisco Vicente Vianna. Relatórios, caixa 60. Reg. 0603, p. 4.

Esses dados demonstram o quanto era comum o trânsito de um mesmo grupo de pessoas na direção de diversas sociedades mutualistas de trabalhadores. Parte desse grupo (33 associados da Bolsa de Caridade) participou da administração de quatro ou mais mutuais, concomitantemente ou não. Essas pessoas certamente contribuíram muito para o crescimento e manutenção das sociedades de auxíliomútuo em Salvador. Elas disponibilizaram tempo e esforço para o sucesso do associativismo operário.

\section{O corpo diretivo da Sociedade Bolsa de Caridade}

Além da intensa participação de seus membros na direção de outras mutuais, alguns associados exerceram cargos administrativos na Sociedade Bolsa de Caridade por longo período. Identifiquei 25 associados que atuaram como dirigentes dessa associação por mais de dez anos, seja em anos seguidos, seja de forma intermitente. Nem os relatórios anuais da associação, nem os jornais, mencionam a existência de chapas de oposição, campanhas eleitorais, disputas nas assembleias ou qualquer outro indício de concorrência para os cargos administrativos dessa 
mutual. Os estatutos estabeleciam que a eleição dos dirigentes da SBC fosse atribuição da Assembleia Geral, sem detalhar seu funcionamento, sendo vedada a recusa aos cargos, sob pena de o filiado ter seus direitos suspensos. Em face do silêncio das fontes, não posso afirmar as razões que levaram esses associados a permanecer por diversos exercícios, seguidamente ou não, à frente de cargos na agremiação. $O$ fato é que um grupo político parece ter se estabelecido de modo burocrático na direção da associação por longos anos, sobretudo a partir de 1910, como veremos adiante. Em artigo onde questiona o caráter democrático das associações de ajuda mútua, Adhemar Lourenço da Silva Júnior apontou para a existência de uma burocracia dirigente nessas associações. Para tanto, o autor analisou o funcionamento das assembleias e os procedimentos eleitorais nas mutuais do Rio Grande do Sul. Corroboraria para a burocratização das mutuais o fato de a Assembleia Geral, que seria a instância de democratização por excelência, ser pouco frequentada.

Se o exercício de cargos, na entidade, nem sempre trazia prestígio ou benefícios (a ponto de ser, amiúde, obrigatório) e, mesmo quando trazia, impunha ao eleito tarefas (executadas também conforme regras) e responsabilidades (pelas quais poderia ser cobrado e, mesmo, deposto) é previsível que haja uma baixa renovação nos quadros de dirigentes. ${ }^{45}$

Ainda que o interesse para assumir os encargos inerentes à administração da associação tenha sido pequeno, a ponto de não haver registro de chapas concorrentes nas eleições anuais, não acredito que essa explicação encerre a questão. Independente dos interesses e motivações que levaram diversos associados a permanecer por diversos exercícios, contínuos ou intercalados, nos cargos administrativos da Bolsa de Caridade, o fato é que eles dedicaram parte do seu tempo livre, sem contrapartida financeira oficial, à gestão da mutual. Foi o caso do sócio fundador, Antônio Borges Nogueira, que também era vinculado ao Centro Operário da Bahia. Em 1890, ele ocupou o cargo de porteiro da Secretaria do Senado ${ }^{46}$, foi escrivão de paz em $1892^{47}$, candidato a Juiz de Paz pela chapa Federalista da Freguesia dos Mares ${ }^{48}$, tendo falecido no Rio de Janeiro, em fevereiro de 1927, onde residia. Além de fundador e reorganizador da associação, ele presidiu o Conselho Diretório, a mesa da Assembleia Geral e foi membro do Conselho Fiscal.

45 SILVA JÚNIOR, Adhemar Lourenço da. Oligarquias em sociedades de socorros mútuos (1854-1940). Revista Mundos do Trabalho, Florianópolis, v.2, n. 4, p. 942010.

46 Almanak Administrativo, Indicador e Noticioso do Estado da Bahia para 1898 Organizado por Antonio Alexandre Borges dos Reis. Bahia: Wilcke, Picard e Cia., 1899.

47 Jornal de Notícias, Salvador, 17 jun. 1892, p. 1.

48 Jornal de Notícias, Salvador, 13 dez. 1892, p. 2. 
Foram pelo menos 28 anos de atuação nas diversas esferas da gestão da SBC. Por sua dedicação, recebeu o título de benemérito e, após sua morte, teve seu retrato fixado no salão nobre da associação. ${ }^{49}$

Outro caso interessante foi o de Antonio Bento Guimarães, "artista" carapina, mestiço, ex-mestre da oficina de obras brancas do extinto Arsenal de Guerra da Bahia $^{50}$, residente no distrito dos Mares, onde foi eleito Juiz de Paz por várias vezes, entre 1876 e $1903 .{ }^{51}$ Nesse sentido, vale a pena ler o comunicado publicado em 1876, ao ter sucesso em sua primeira eleição:

\footnotetext{
Ao público Saberemos cumprir com os nossos deveres.

Freguesia dos Mares, 7 de outubro de 1876.

Lucas Benício dos Santos

Antônio Bento Guimarães

Antonio Dias de Araujo Pinto. 52
}

Quando organizamos a Chapa Popular de Artista - nesta paróquia - não hasteamos a bandeira de nenhum dos partidos políticos militantes, quisemos unicamente demonstrar que os artistas aqui residentes poderiam, unidos, pleitearem os seus direitos nas urnas - fomos guiados apenas pelo espírito de classe e uma vez por todas declaramos que não estamos adstritos nem aos conservadores, nem aos liberais, temos compromissos e deveres de honra para com os nossos dignos companheiros que nos elegeram, únicos dos quais somos obrigados e aos quais agradecemos os esforços, constância e boa vontade empregados.

O discurso de Antônio Bento Guimarães e seus companheiros, colocando seu mandato a serviço dos "artistas" da paróquia dos Mares ${ }^{53}$, aos quais ele atribuiu sua vitória, pode ser um indício do potencial do associativismo mutualista para a eleição de trabalhadores, no âmbito municipal naquele momento. Uma vez que sua candidatura esteve desvinculada dos partidos existentes à época, é provável que seu nome tenha ganhado alguma projeção, em virtude de sua atuação junto à Sociedade Bolsa de Caridade e à Beneficente União das Classes. ${ }^{54}$ Além de ter exercido a vice-

49 RELATÓRIO do Exercício de 1926 a 1927 Apresentado à Assembleia Geral da Socidedade Bolsa de Caridade pelo Presidente do Diretório Florencio da Silva Friandes. Bahia: Imprensa Moderna, 1927. p. 10.

50 Almanak Administrativo, op. cit., 1898, p. 301.

51 Correio do Brasil, Salvador, 14 out. 1903, p. 2.

52 O Monitor, Salvador, 8 out. 1876, p. 3.

53 A partir de 1892, os estatutos da Sociedade Bolsa de Caridade estabeleceram que a sede da agremiação ficasse circunscrita às freguesias dos Mares e Pilar, provavelmente por estarem concentrados aí os seus associados. ESTATUTOS e Regimento Interno da Sociedade Bolsa de Caridade Aprovados em Sessão de 23 de Março de 1892. Bahia: Tipografia do Diário da Bahia, 1892. p. 1.

54 Para uma análise específica da participação dos trabalhadores nas eleições imperiais, cf. CASTELLUCCI, Aldrin A. S. Muitos votantes e poucos eleitores: a difícil conquista da cidadania operária no Brasil Império (Salvador, 1850-1881). Varia História, Belo Horizonte, v. 30, n. 52, p. 183-206, jan./abr. 2014. 
presidência da Assembleia Geral da Sociedade Beneficente União das Classes, de 1897 a 1899 e em 1903, ${ }^{55}$ ele prestou serviços como membro do corpo dirigente da Sociedade Bolsa de Caridade, nas funções de tesoureiro, vice-presidente da Assembleia Geral, presidente e vice-presidente do diretório, entre 1875 e 1904.

Segundo Silva Jr. "Em qualquer associação, os grupos dirigentes obtêm tal posição por meio do manejo de pelo menos um de dois tipos de recursos: o prestígio externo à associação e o prestígio interno". ${ }^{56}$ Ainda que a dimensão mais evidenciada na atuação da Sociedade Bolsa de Caridade fosse a previdenciária e na função de instituição procurasse manter-se afastada das disputas eleitorais, é bem provável que os associados canalizassem seus votos nos pleitos municipais para pessoas identificadas como representantes dos seus interesses de classe, ofício ou, pelo menos, da agremiação de ajuda mútua da qual faziam parte. Assim, como observou Aldrin Castellucci para o caso do Centro Operário da Bahia, não somente o prestígio interno de um membro da direção tinha o potencial de alçá-lo a um cargo eletivo municipal, como também "a ocupação de mandatos eletivos no aparelho de Estado retroalimentava a continuidade ou possibilitava a retomada do controle das organizações dos trabalhadores". ${ }^{57}$

José Prudencio Ferreira de Carvalho foi proprietário da tipografia Imprensa Moderna de 1896 a $1903 .{ }^{58}$ Posteriormente, assumiu a direção da Tipografia e Encadernação do Liceu de Artes e Ofícios, cujo maquinário fora transferido, de sua antiga tipografia, mediante contrato. Foi premiado com medalha de ouro na Exposição Nacional realizada no Rio de Janeiro, em 1908, e fez constar esse feito nas capas dos relatórios impressos pelo Liceu de Artes, onde seu contrato permaneceu vigente até 1925. Não é demais lembrar que esse personagem imprimiu os relatórios de inúmeras associações de socorros mútuos, entre o final 1896 e 1925, inclusive das oito mutuais das quais ele era dirigente, a exemplo da Sociedade Bolsa de Caridade, onde ocupou a presidência do diretório, ininterruptamente, entre 1910 e 1925.

Durante a sua gestão, Prudencio de Carvalho (Figura 1) montou um grupo político que o acompanhou por 15 anos. Entre 1910 e 1925, poucos foram os cargos onde houve alternância de nomes e, ainda assim, em função de doença, morte ou "força maior". Além do tipógrafo, Prudêncio de Carvalho na presidência, o Conselho Diretório foi composto

55 Almanaque Administrativo, Indicador, Noticioso, Comercial e Literário do Estado da Bahia Para o ano de 1903. Bahia: Reis e Cia., 1903. p. 472.

56 SILVA JUNIOR, Adhemar Lourenço. As sociedades de socorros mútuos: estratégias privadas e públicas (estudo centrado no Rio Grande do Sul, 1854-1940). 2004. Tese (Doutorado em História) - Pontifícia Universidade Católica do Rio Grande do Sul, 2004. p. 253.

57 CASTELLUCCI, op. cit., 2015, p. 194.

58 Almanaque, op. cit., 1903, p. 585.

Revista Mundos do Trabalho | Florianópolis | vol. 11 | 2019 | p. 1-29 
por: Cândido Honório Pinto, vice-presidente de 1911 a 1923; pelo carapina Florêncio da Silva Friandes (Figura 2), $1^{\circ}$ secretário de 1910 a 1925; Miguel Archanjo de Souza, 2ํำ secretário de 1910 a 1925; pelo empregado público Liberato José de Freitas, tesoureiro de 1910 a 1925; Liberato Gomes dos Anjos, recebedor de 1910 a 1925; Antônio Nogueira da Silva, visitador de 1913 a 1926; Genésio Américo de Lacerda, arquivista, de 1906 a 1914, sendo substituído pelo mecânico José Zacharias dos Santos (Figura 4); além dos síndicos Honorato de Britto Lima e Faustino do Sacramento Senna. O síndico tinha a função de verificar se os candidatos a sócios efetivos, propostos ao Conselho, cumpriam as exigências estatutárias.

Figura 3

Prof. Presciliano José Leal Presid. Assembleia (1911-1916)

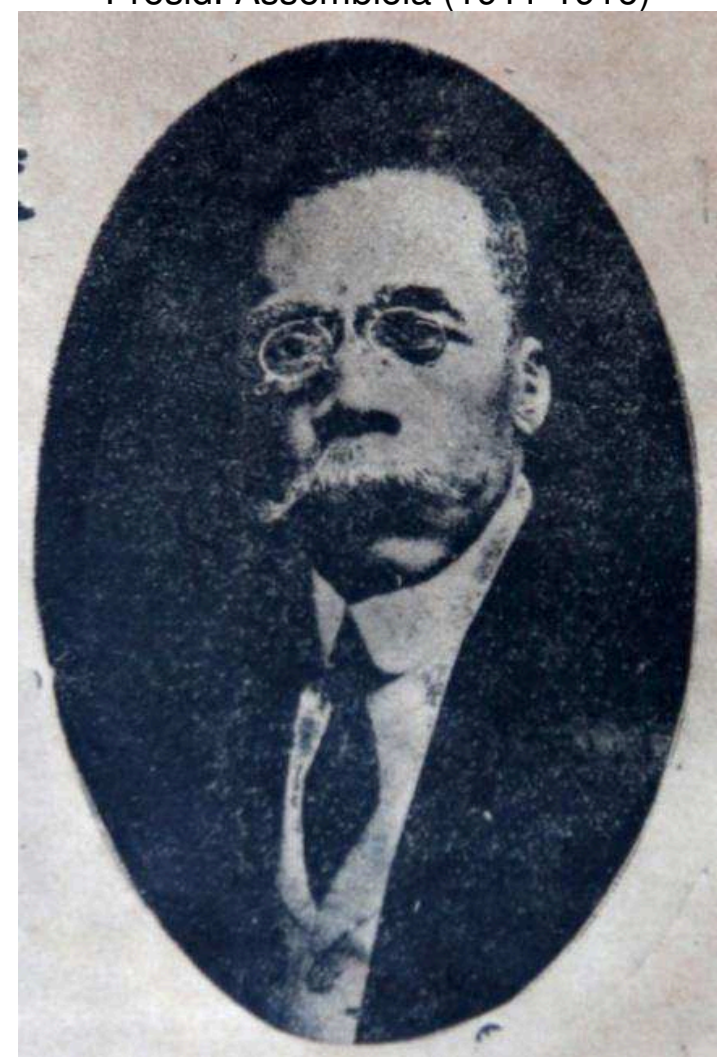

Figura 4

José Zacharias dos Santos Arquivista (1916-1928)

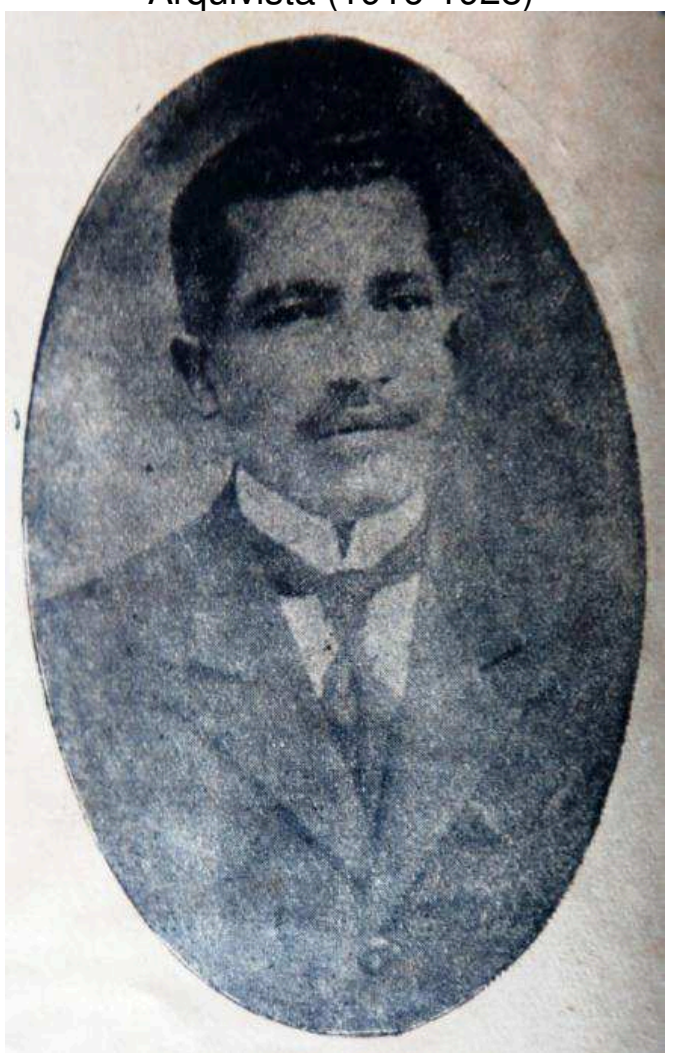

Fonte: Relatório da Sociedade Bolsa de Caridade - Cinquenta anos de existência. 1872-1922, Bahia: 1922. APEB. Biblioteca Francisco Vicente Vianna, Relatórios, caixa 60. Reg. 0603, p. 4.

Pouco pude apurar sobre esses dirigentes. De todo modo, o silêncio das fontes parece indicar que seriam pessoas ligadas ao mundo laboral, que apesar de precisarem trabalhar para garantir a sobrevivência, arranjavam tempo para o trabalho voluntário. Os membros do Conselho Diretório deveriam dedicar pelo menos duas noites por mês às reuniões do Conselho Diretório, cabendo-lhes cuidar das tarefas administrativas, incluindo inventário, contabilidade, listas de sócios, diplomas, 
concessão e suspensão de benefícios, admissão de sócios, entre outras atribuições. Certamente poderia haver ganhos financeiros indiretos, como comprova a preferência dada à tipografia dirigida por Prudêncio de Carvalho, já mencionada anteriormente.

Já a carga de trabalho dos membros da mesa da Assembleia Geral era consideravelmente menor do que a dos membros do Conselho Diretório. As sessões da Assembleia Geral aconteciam poucas vezes por ano, sendo as magnas comemorativas de aniversário as mais concorridas. As assembleias ordinárias deveriam acontecer quadrimestralmente e as extraordinárias sempre que os interesses sociais o exigissem. Essa foi a única instância em que os cargos da mesa da Assembleia Geral foram ocupados majoritariamente por profissionais liberais, que se revezavam nos cargos, em especial na presidência e vice-presidência.

Nos 15 anos em que Prudêncio de Carvalho ficou à frente do Diretório, os principais cargos da Assembleia Geral foram ocupados por membros das duas categorias emblemáticas do fenômeno clientelista: políticos e médicos. Estes últimos não cobravam pelos serviços prestados aos associados da Bolsa de Caridade e era comum que integrassem a diretoria de várias outras associações, fossem de socorro mútuo ou filantrópicas. Adhemar Lourenço da Silva Júnior encontrou situação similar em sua pesquisa sobre o Rio Grande do Sul: "Contudo, era frequente que médicos exercessem gratuitamente suas atividades nas entidades". Como não havia "remuneração contratada", as "compensações simbólicas" ganhavam relevância, "tal como também acontece em relações clientelares de troca de favores". 59 Talvez não fosse precipitado sugerir que justamente aquela que poderia ser a mais soberana instância deliberativa, concebida como espaço democrático de autonomia e participação, refletisse as relações clientelistas que perpassavam a associação.

No mesmo período, a Comissão Fiscal foi composta basicamente pelo sócio fundador e benemérito, o major Antonio Borges Nogueira, que exercia a função de porteiro da secretaria do Senado Estadual, desde 1890; por Faustino da Silva Friandes (Figura 5); pelo sócio benemérito, major Herculano Brittes Guimarães (Figura 6); e pelo sócio benemérito, capitão da Guarda Nacional, Euthymio da Cruz Baptista. Esse último devia ter uma boa condição de vida, posto que ao morrer, em 1940, aos 68 anos, deixou vários imóveis para a família, sendo o único membro de cor branca entre os citados.

59 SILVA JÚNIOR, op. cit., p. 367. 
Figura 5

Faustino da Silva Friandes

Comissão Fiscal (1910-1920)

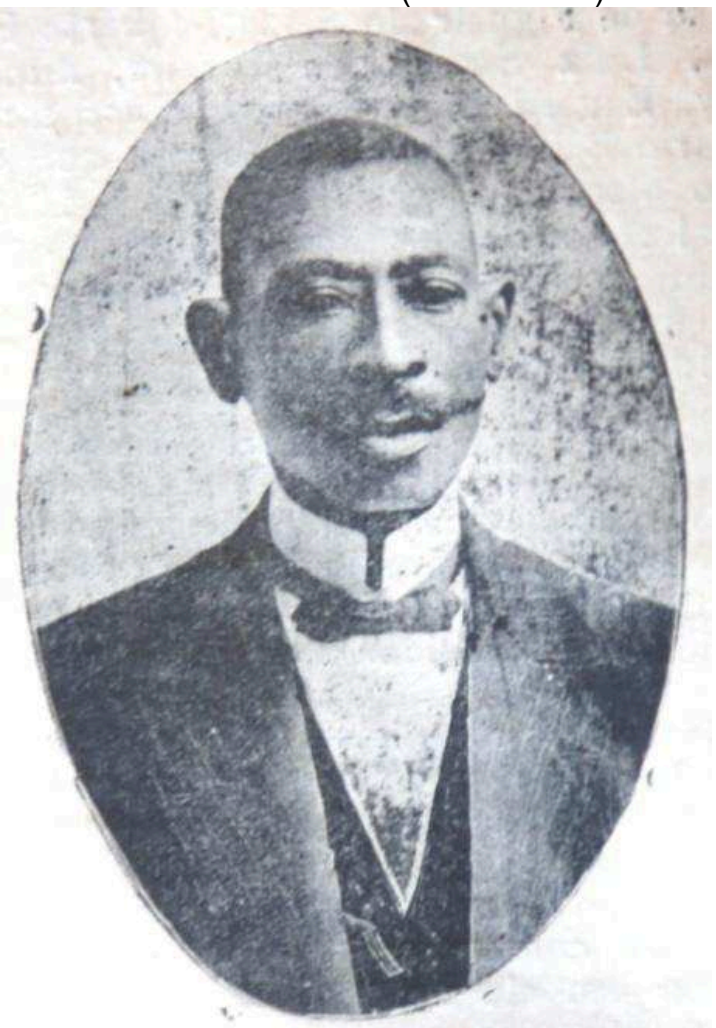

Figura 6

Herculano Brittes Guimarães

Benemérito. Com. Fiscal (1910-1920)

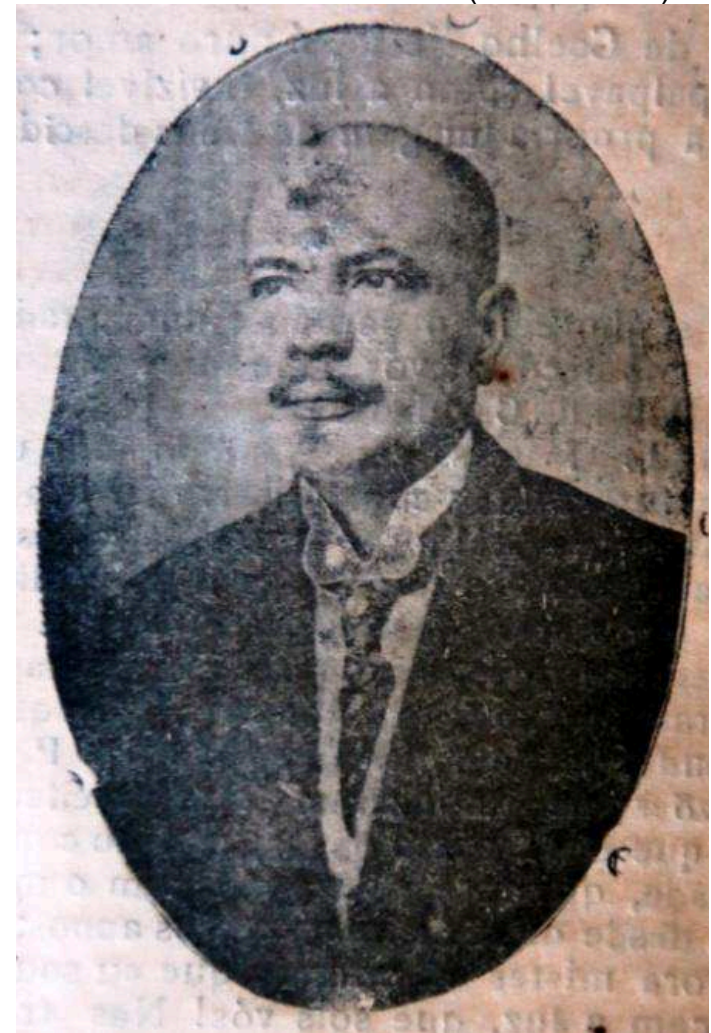

Fonte: Relatório da Sociedade Bolsa de Caridade - Cinquenta anos de existência. 1872-1922, Bahia: 1922. APEB. Biblioteca Francisco Vicente Vianna, Relatórios, caixa 60. Reg. 0603, p. 4.

De qualquer modo, é importante notar que tanto o Conselho Diretório, quanto a comissão fiscal da associação, tiveram o predomínio de trabalhadores durante todo o período pesquisado, apesar da presença de sócios pertencentes a outras classes sociais no corpo geral de sócios da SBC. Apenas a Assembleia Geral fugiu a esse padrão, após 1910, quando passou a eleger, preferencialmente, políticos e profissionais liberais para os seus principais cargos. Entretanto, é preciso reconhecer a heterogeneidade dos trabalhadores associados. Mesmo entre os "artistas", a diferença de posses e de acesso à cultura formal podia ser grande. O próprio Prudêncio de Carvalho não era um simples tipógrafo, mas possuidor dos maquinários e proprietário de tipografia. 


\section{Considerações Finais}

A Sociedade Bolsa de Caridade era uma associação de auxílio-mútuo, majoritariamente composta por trabalhadores e atuante em defesa dos interesses dos trabalhadores, ainda que abrigasse indivíduos pertencentes a outros grupos e classes sociais. Esses, por sua vez, em geral não precisavam do amparo financeiro da SBC. Seu envolvimento era ditado pela cultura paternalista e pelas práticas clientelistas que permeavam as relações sociais no Brasil do período. A título de exemplo, cito a entrega do título de sócio benemérito aos deputados provinciais, Antônio Bahia da Silva Araujo e Alexandre Herculano Ladislão, apontados como os responsáveis pela subvenção estatal no valor de 1:000\$000, aprovada em 21 de julho de $1888 .^{60}$ Este último faleceu pouco tempo depois, tendo sua viúva, fato incomum, requerido os socorros da associação, tendo recebido os $100 \$ 000$ do auxílio funeral, como determinava os estatutos. ${ }^{61}$

Apesar de sua composição pluriclassista, é plausível classificá-la como integrante do associativismo operário, não só em razão de ter sido fundada por trabalhadores para ajudarem-se mutuamente, como por ter seu corpo diretivo fundamentalmente ocupado por artesãos, mestres de ofício e pequenos funcionários públicos, e, especialmente por sua base de sustentação econômica: as mensalidades dos associados, ainda que tenha contando com subvenção estatal por um período de 16 anos, dos 57 em análise.

A adesão de membros da classe média ou das elites econômicas e políticas, notadamente dos profissionais liberais e dos políticos, certamente contribuiu para disseminar a ideia da cooperação entre as classes sociais, mas não poderia apagar a experiência de se saber trabalhador e do lugar que ele ocupava no mundo de então. A Bolsa de Caridade não foi uma associação criada pela elite para fazer caridade aos mais pobres, não era o produto de relações verticais. Era uma associação operária que se sustentava a si mesma, fundada em relações horizontais de solidariedade. Apesar das relações clientelistas e paternalistas imporem limites à ação de seus membros, elas não comprometiam integralmente a autonomia da associação,

60 RELATÓRIO da Sociedade Bolsa de Caridade Apresentado em Sessão de 12 de Maio de 1889 pelo Presidente do Conselho Elpídio Adolpho de Menezes. Bahia: Lytho-Tipographia de J. G. Tourinho, 1889. p. 5.

61 RELATÓRIO da Sociedade Bolsa de Caridade Apresentado em Sessão de 11 de Maio de 1890 pelo Presidente do Conselho Elpídio Adolpho de Menezes. Bahia: Lytho-Tipographia de J. G. Tourinho, 1890. p. 8. 
mesmo porque a autonomia total não era uma aspiração da associação, visto que contava em sua história com subvenção estatal direta, isenção de impostos e serviços médicos gratuitos para os seus associados. Além disso, não só os Estatutos dispunham de mecanismos garantidores de autonomia, a exemplo da Assembleia Geral, como também a solidez financeira da associação, respaldada majoritariamente pela contribuição dos sócios. Por outro lado, a participação das elites nas associações de trabalhadores, em última análise, também revela os limites da autonomia política das classes dominantes. ${ }^{62}$

A percepção do potencial das sociedades de ajuda mútua, como base eleitoral, não é suficiente para explicar o grande número de associados da Bolsa de Caridade atuando qual partícipes do quadro diretivo de diversas mutuais, quase sempre concomitantemente e, muitas vezes, por longos períodos. Apenas 5\% deles disputaram eleições, fato que deixa sem explicação a motivação dos outros $95 \%$. Com efeito, dos 224 associados da Bolsa de Caridade que exerceram cargos na administração de outras sociedades de ajuda mútua, identifiquei apenas 14 que pleitearam, com ou sem sucesso, cargos eletivos.

Alguns trabalhadores perceberam que participar da direção das associações de socorros mútuos poderia Ihes render benefícios. O prestígio ou o poder inerente ao cargo também poderia ser usado para obter privilégios no mercado de trabalho. É provável que, tanto o tipógrafo Prudencio de Carvalho, quanto o armador João Pedro Rodrigues Lima, tenham sido beneficiados em razão dos cargos que ocupavam, posto que ambos costumavam prestar serviços a diversas associações das quais eles próprios eram dirigentes. Outra característica em comum é que os dois eram proprietários dos seus instrumentos de trabalho e possivelmente tinham outros trabalhadores a seu serviço, fosse de forma permanente ou temporária. Apesar de ter identificado apenas esses dois exemplos, acredito que essa não devia ser uma situação incomum.

Porém, a expressiva participação de associados da Bolsa de Caridade na direção de outras sociedades de ajuda mútua não pode ser explicada apenas em função das relações paternalistas e clientelistas, comuns às associações mutuais, ou pela possibilidade de auferir vantagens no mercado de trabalho. Há que se considerar a participação dos trabalhadores e o seu protagonismo no esforço para

62 Sobre esse aspecto, cf. LIMA, Celina Batalha Oliveira. Do Arsenal de Guerra para o mundo operário mais amplo: um estudo sobre a Sociedade Bolsa de Caridade (18721930). 2019. Dissertação (Mestrado em História) - Universidade do Estado da Bahia, Alagoinhas, 2019. 
fundar e manter as associações de ajuda mútua, vistas como um espaço de proteção, socialização e reforço de laços identitários para uma parcela da classe trabalhadora. ${ }^{63}$

O prestígio do cargo, a participação voluntária, a militância pela ampliação da cidadania dos trabalhadores e da solidariedade, também ajudam a entender as motivações que levaram esses trabalhadores a dedicar seu tempo livre à causa mutualista.

Recebido em 05/08/2019 Aprovado em 26/09/2019

63 Claudio Batalha afirma que a ideia de que o associativismo, de forma geral, contribuiu para reforçar os laços identitários é largamente aceita pela historiografia. Porém, poucas sociedades mutualistas de trabalhadores contribuíram efetivamente para a "construção de uma identidade de classe, essencial no processo de formação da classe operária". BATALHA, Claudio H. M. Relançando o debate sobre o mutualismo no Brasil: as relações entre corporações, irmandades, sociedades mutualistas de trabalhadores e sindicatos à luz da produção recente. Revista Mundos do Trabalho, Florianópolis, v. 2, n. 4, 2010. 